\title{
Sand transport characterization on the foredune area of Parangtritis, Indonesia
}

\author{
Mukhamad Ngainul Malawani ${ }^{1, *}$, Djati Mardiatno ${ }^{1,2}$, and Sunarto ${ }^{1}$ \\ ${ }^{1}$ Department of Environmental Geography, Universitas Gadjah Mada, Indonesia \\ ${ }^{2}$ Center for Disaster Study, Universitas Gadjah Mada, Indonesia
}

\begin{abstract}
The aim of the research are to determine the characteristics of sand deflation on Parangtritis foredune area. The development of tourism activity on surrounding area could be has a big impact to the sand transport process. Data required in this research are wind direction and its speed, the sand mass collected from sand sampler, sand grain size, roundness and sphericity, and interview from tourists. Sand that transported by wind collected by sand sampler with dimension of $0.76 \mathrm{~cm}$ height and $1 \mathrm{~cm}$ width. Sand transport rate or deflation calculated by Bagnold's formula. The results showed that the deflation process is bigger at daytime observation that at night, it is average $2.42 \mathrm{~g} \cdot \mathrm{m}^{-1} \mathrm{~s}^{-1}$ during day and $0.03 \mathrm{~g} \cdot \mathrm{m}^{-1} \mathrm{~s}^{-1}$ during night. Each samples location have different deflation characteristics of material that transported. Grain diameters ranging from $0.318 \mathrm{~mm}$ to $0.395 \mathrm{~mm}$ with dominance texture is medium sand. Sphericity and roundness of sediment material was on a scale of 0.5 and 0.7 . This natural process that occurred on the research area didn't knowing well either by local communities or tourists. Therefore need some proper management for support the continuity of deflation process for supplying material to the main sand dune area of Parangtritis.
\end{abstract}

\section{Introduction}

Aeolian processes on some location could combine with marine processes. This phenomena occurred in the Parangtritis coastal area. Source of sand material deposited in sand dune near Parangtritis originated from Merapi Volcano [1]. Sand dune in coastal areas is naturally attractive for tourism purpose [2,3]. Coastal dune formed in Parangtritis coastal area relatively flat with various dune type. Sand on beaches with fine size transported by aeolian process would formed coastal sand dunes with relatively flat morphology [4]. It is indicated that sand materials in Parangtritis tend to have fine sand grain size. Sand transport on dune are related to the wind speed. Sand or dust movement with active transportation caused by wind activity is called deflation [5]. Wind speed at $5 \mathrm{~m} / \mathrm{sec}$ caused sand started to move. However, when wind already at constant speed sand started to move at wind speed $4 \mathrm{~m} / \mathrm{sec}[6]$.

Previous studies estimated that $50-75 \%$ of eroded sand material by wind move on saltation, 3-40 \% move by floating, and 5-25\% move on creeping [5]. The wind blows on Parangtritis coastal area mostly originated from southeast because wind blowing to land deflected by karst hill on Gunungsewu in east part of Parangtritis. Strong wind always transported sand from foredune to main dune on northwest part from Parangtritis beach. Combination between strong wind and sand humidity caused many sand transported to main dune, especially on summer season. The wind speed caused sand moving on different ways, like creeping, saltation, and floating in the air. This condition indicated that on Parangtritis foredune area sand deflation are significantly happen. The generate process on this research area quite similar with dune filed on Petagonia, Argentina. Wind from Pacific Ocean reaching Andes contribute to a rain shadow which generates true desert condition [7] The deflation process occurred in foredune Parangtritis which supply material on main dune has azimuth of $335^{\circ}-340^{\circ}$ from the direction of Gunungsewu karst area and has two kilometers width [8]. Sand transport or deflation on Parangtritis has different process form arid region, like in China. On arid region, the greatest sand deflation commonly conducted in such material form lacustrine sand and alluvial sand [9].

Sand materials on Parangtritis foredune moved by creeping has $84.81 \%$ form total material moved. Others $15.17 \%$ moved by saltation, and only $0.02 \%$ mover by floating [10]. The difference percentage of sand movement caused by vegetation coverage, material sources, and wind speed. The rapid development of tourism area caused some threats to the continuity of sand transport to the main dune of Parangtritis. In this research we try to analyze the role of foredune area for transporting primary material to the main dune, especially the characteristic of sand transported by wind or called by deflation process. Many studies have been learn about deflation process and its numerical calculation. Summarized some methods in calculation of the deflation process showed in Table 1 [11]. Even various formulas for estimating sand transport has been published, sand transport on field measurement is a difficult project [12]. On this research, sand transport on foredune Prangtritis calculated by Bagnold's formula.

\footnotetext{
* Corresponding author: malawani@ugm.ac.id
} 
Table 1. Some formulas for calculating the sand transport rate.

\begin{tabular}{|c|l|l|}
\hline No. & \multicolumn{1}{|c|}{ Formula } & \multicolumn{1}{|c|}{ Source } \\
\hline 1 & $\mathrm{q}=\mathrm{C}(\mathrm{d} / \mathrm{D})^{0.5}(\rho / \mathrm{g}) \mathrm{V}^{3}$ & Bagnold $(1941)$ \\
\hline 2 & $\mathrm{q}=\mathrm{C}(\mathrm{d} / \mathrm{D})^{0.75}(\rho / \mathrm{g}) \mathrm{V}^{3}$ & Zingg $(1953)$ \\
\hline 3 & $\mathrm{q}=(1 / \mathrm{gd})^{1.5} \mathrm{e}^{(4.97 \mathrm{~d}-0.47)} \mathrm{V}_{*}{ }^{3}$ & Hsu $(1971)$ \\
\hline 4 & $\mathrm{q}=\mathrm{C}\left(1-\mathrm{R}_{\mathrm{t}}{ }^{2}\right)(\rho / \mathrm{g}) \mathrm{V}_{*}{ }^{3}$ & Kind $(1976)$ \\
\hline 5 & $\mathrm{q}=\mathrm{CV}^{3}(\mathrm{C}=0.03)$ & $\begin{array}{l}\text { O'Brien and } \\
\text { Rindlaub }(1936)\end{array}$ \\
\hline $\begin{array}{l}\mathrm{C}: \text { Coefficient } ; \mathrm{D}: \text { standard sand diameter; d: grain diameter } \\
\rho: \text { air density } ; \mathrm{g}: \text { gravity } ; \mathrm{V}_{*}: \text { wind speed gradient } ; \mathrm{R}_{\mathrm{t}}: \mathrm{V}_{*} / \mathrm{V}_{*_{\mathrm{t}}}\left(\mathrm{U}_{*}:\right. \\
\text { threshold velocity) } ; \mathrm{V}: \text { wind speed. Source: Dong et al. }(2003)\end{array}$ \\
\hline
\end{tabular}

\section{Methods}

Measurement of deflation process conducted in sequential time, between $07.00 \mathrm{am}$ in the morning to $17.00 \mathrm{pm}$ in the afternoon. However, measurement also conducted in evening started in $19.00 \mathrm{pm}$ to $05.00 \mathrm{am}$. Both of them conducted on five different locations. This method derived because sand transport by wind fluctuated over temporal and spatial scales [13]. Sand sampler used in this research adopt design from Bagnold's design [14] with a little adjustment due to different climate and meteorological condition. Sand sampler has high $0.76 \mathrm{~cm}$ with two sand collector for creeping material and saltation material showed on Figure 1a.
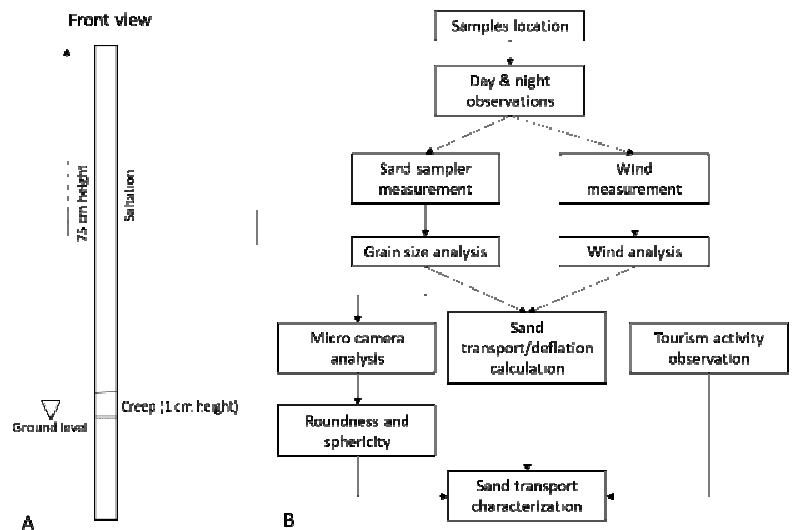

Fig. 1. (a) Sand sampler design for collecting sand movement, (b) Research flowchart for sand transport characterization.

Wind data both speed and direction measured by hand anemometer at height of 2 meters from ground surface. Interview data obtained on the same time with sand deflation collection with type of respondent are tourism. Grain size analysis performed by Gradistat to measure value of sorting, skewness, and kurtosis [15]. For sand transport calculation, Bagnold's formula obtained as mentioned in Table 1 . Workflow on this research showed on Figure 1b. Microscopic observations also performed using a micro-camera to photograph small-sized objects of sand samples and to conduct the measurement of roundness and sphericity index. The research location showed in Figure 2.

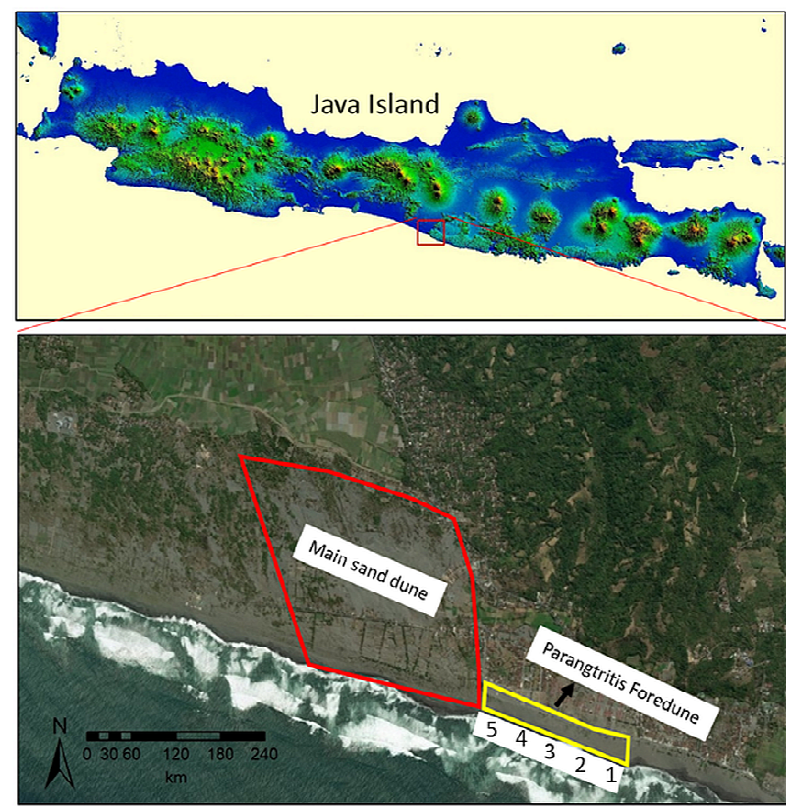

Fig. 2. Research area on sand dune Parangtritis, Yogyakarta, Indonesia.

\section{Results and discussions}

Result from field measurement, wind direction and speed have different condition on the morning and evening observation. Wind on the morning to afternoon condition generally at speed class of light breeze $(6-11 \mathrm{~km} / \mathrm{h})$ up to moderate breeze $(20-28 \mathrm{~km} / \mathrm{h})$ within Beaufort's scale, which direction towards northwest (NW). On evening condition, wind blowing with class speed calm (0-1 $\mathrm{km} / \mathrm{h}$ ) up to gentle breeze $(12-19 \mathrm{~km} / \mathrm{h})$ with direction to west (W) and northwest (NW ). On evening condition, wind speed have vary Beaufort's scale ranging from calm, light air, light breeze, and gentle breeze. Based on this result, wind speed on evening counting more slowly than afternoon condition, but the direction have the same condition. Wind rose from measurement on five location drown on afternoon and evening condition showed in Figure 3. This wind speed and direction has strong connection the sand transport due to its genetic. Wind speed would generate sand on the upper ground started to move and eroded. Ripple direction also indicated the wind direction occurred on the research area. From the differences between day and night wind speed, its implied that deflation or sand transport would occurred bigger at daytime because the wind is much bigger than at night. 

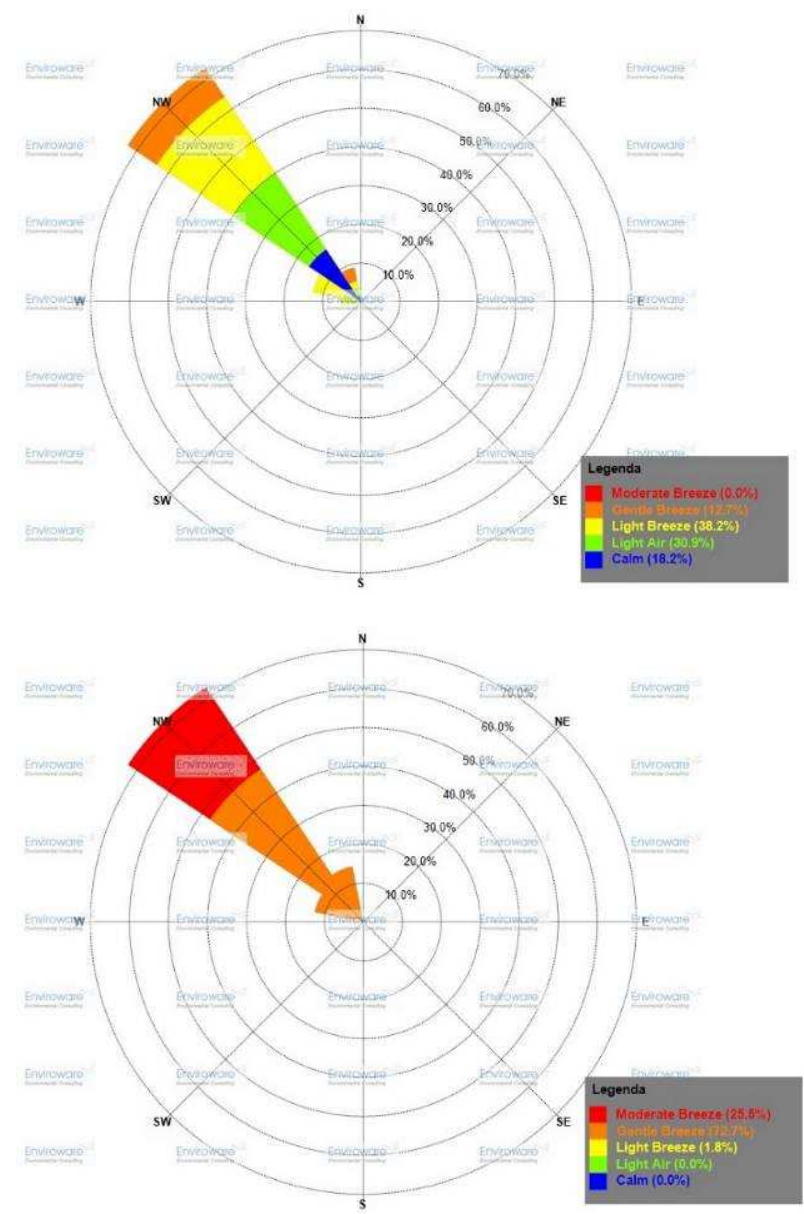

Fig. 3. Wind rose from total measurement on five locations. Upper one wind rose is evening condition and on the below one is wind rose for daytime condition.

Differences between wind speeds in the morning to evening condition would influence to deflation rate. High deflation rate measured on the morning to afternoon condition with average value on sand transport 2.42 g. $\mathrm{m}^{-1} \mathrm{~s}^{-1}$. Contrary, small deflation occurred on evening condition with average value of sand transport at $0.08 \mathrm{~g} . \mathrm{m}^{-1} \mathrm{~s}^{-1}$. On the night observation, sand transport almost zero, which is mean there was no sand movement during night. This is caused by the small wind and high humidity due to sea breeze. Sand transport on this research calculate with Bagnold's formula as shown in Table 1. The result of sand transport (q) calculation on the research area has different result with other measurement in USA and Brazilian coastal dune. Sand transport on Parangtritis foredune area categorized as a small value of sand movement compared to coastal dune in USA and Brazilian which amount of sand transport (q) over 25 g.m $\mathrm{m}^{-1} \mathrm{~s}^{-1}$ [13]. The differences of geological setting and sand material of both area caused the sand transport rate was very significant. Wind speed also quite different, where research area has deviation over 3$4 \mathrm{~m} / \mathrm{s}$ below from wind speed on coastal dune in USA and Brazilian. The detailed sand transport measurement conducted in five different points on the foredune area of Parangtrtitis shown in Table 2.
Table 2. Deflation rate in the foredune area of Parangtritis.

\begin{tabular}{|c|c|c|c|c|}
\hline Location & $\begin{array}{c}\text { Day } \\
\mathbf{q}(\mathbf{g} . \\
\left.\mathbf{m}^{-1} \mathbf{s}^{-1}\right)\end{array}$ & $\begin{array}{c}\text { Wind } \\
\text { Speed } \\
\text { (day) } \\
\text { (m/s) }\end{array}$ & $\begin{array}{c}\text { Night } \\
\mathbf{q}(\mathbf{g} . \\
\left.\mathbf{m}^{-1} \mathbf{s}^{-1}\right)\end{array}$ & $\begin{array}{c}\text { Wind } \\
\text { Speed } \\
\text { (night) } \\
(\mathbf{m} / \mathbf{s})\end{array}$ \\
\hline 1 & 2.15 & 4.8 & 0.03 & 1.2 \\
\hline 2 & 1.41 & 4.2 & 0.03 & 1.2 \\
\hline 3 & 2.12 & 4.9 & 0.03 & 1.2 \\
\hline 4 & 3.35 & 5.4 & 0.21 & 2.2 \\
\hline 5 & 3.01 & 5.2 & 0.14 & 1.9 \\
\hline
\end{tabular}

Result from measurement and sand transport analysis shows that sand move on different value on day and night observation. Otherwise, both sand transported on day and night have different characteristic. On location sampler 1, 2, and 3 the average sand diameter range from $0.31-0.33 \mathrm{~mm}$. Those size is smaller than location sampler 4 and 5 , which is $0.39 \mathrm{~mm}$. This grain size in quite different with other researcher measured on coastal dune field, which is 0.398 to $0.533 \mathrm{~mm}$ [13]. From Gradistat analysis also shows that from four different sand size, medium sand is dominance on all samples location. From all samples, medium sand has percentage over $70 \%$, and the smallest sand size is very fine sand with ranging from $1-3 \%$. The amount of sand material transported on foredune Parangtritis showed in Figure 4.

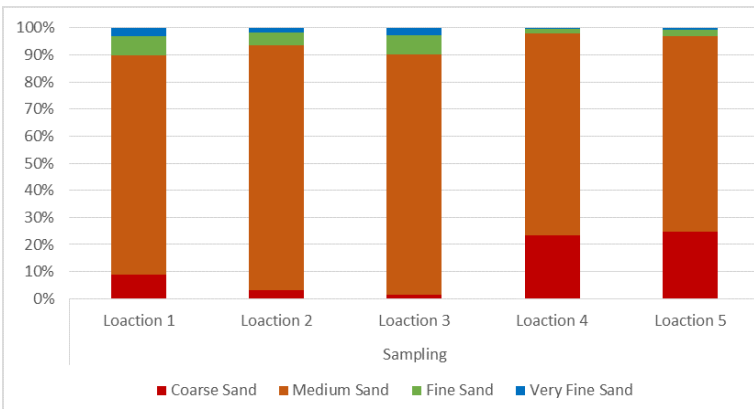

Fig. 4. Comparison of sand texture on different locations. Grain size measured on sand material detached by wind due deflation process.

Sand transported by wind which collected in sand samplers can be analysed for sand movement type. Sand sampler only can collect sand which moves by creeping or saltation. Based on result showed in Figure 5, saltation sand more dominance than creeping sand. From one hour measurement with sand sampler $1 \mathrm{~cm}$ width, location 4 can collected more than 500 gr sand moves by saltation. Both on day and night observation, on this location is more dominance than others location sampler. This result is quite similar with other measurement on main dune, which showed that saltation sand have $>80 \%$ of all sand movement [10]. From this result, can be interpreted that on location 4 and its surrounding is the natural wind corridor that supplied material from foredune to the main dune of the Parangtritis sand dune area. 


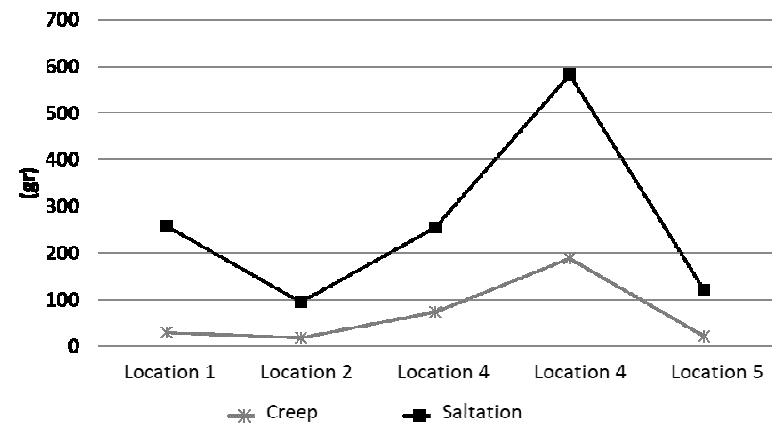

Fig. 5. Comparison of sand movement weight trapped on sand sampler. Saltation sand is bigger than creeping sand.

Sand analysis on foredune also conducted by observation on micro camera. Result from this observation, shows that material transported have different roundness and sphericity. Index of roundness dominated by scale of 0.5 , only location 4 have roundness index of 0.7 . This is indicated that high rate of deflation caused materials tend to have more rounded material than on small rate of deflation. The photograph of sand samples on all sampling site showed by Figure 6 . On the location 4 and 5 , there was a crowd tourism activity like building, road, and some artificial attractive. However, on this location sand transport measured as strongest deflation rate. This caused some tourists and locals mentioned that sand transport was the threat for tourism activity.

Sand dune Prangtritis is quite unique due to its supply material form Merapi Volcano that contain minerals like silica [8]. Those materials transported by Opak River and drifted by longshore and onshore current, continued transported by wind along the foredune to the main dune. This chain process implied that marine processes also have a big impact to the sand transport processes. Therefore, fluvial processes on Opak River also need to be maintained. Developing of sabo dam could be have strong interfere to the material supply on sand dune because sediment grain diameter on the mouth of Opak River was potentially only on silt or clay texture. This is showed that these material is not suitable to be raw material for sand dune material because that is classified to mud or clay material. This genetic scenario caused both fluvial and marine processes has important part to the whole systems of sand dune Parangtritis. Lack of coastal dune protection will cause environmental degradation. Some dune on Catalan coastal dune have been disappeared over $60 \%$ and $30 \%$ of them have been decrease on size because of human intervention [16]. If there is no proper management on coastal dune of Parangtritis, sand dune disappearing phenomena is very potential threaten. Strong human interfere on Parangtritis coastal dune system is indicated that this coastal dune need to be protected immediately.

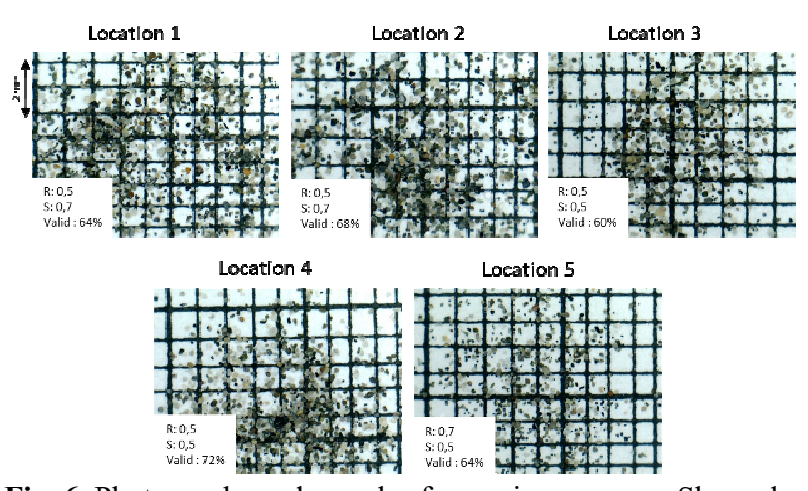

Fig. 6. Photograph sand samples form micro-camera. Showed the magnificent shape of sand granule from all sampling sites.

\section{Conclusion}

Foredune area of Parangtritis took an important role for supplying material to the main dune of Parangtritis. Before transported to the main dune, the deposited material from marine process started to move by wind process at the foredune area. However, because the rapid development of tourism the foredune has been blocked by building or road that caused imbalance for the sand transport rate. This research showed that on the foredune sand move actively by wind and it was indicated that aeolian process has been established on this site. If the tourism development didn't concern about this natural process, the main dune will be lack of material and caused the imbalance of sand transport rate. Many tourists also didn't knew about the deflation process and they were though that deflation is a threat for tourism comfort. We suggest that on the foredune area of Parangtritis need to prepare the zoning area for sand transport and put some notice billboards about the sand transport process for educating to the tourists and locals.

\section{References}

1. H. Th. Verstappen. K.N.A.G. 74. (1957)

2. Virginia Marine Resource Comission. Coastal Primary Sand Dune/Beach Guidline. Virginia, (1993)

3. C.A.M. King. Techniques in Geomorphology. London. Edward Ardnold. (1966)

4. E.C.F. Bird. Coast and Introduction to Systematic Geomorphology. Cambridge. The M.I.T Press. (1969)

5. R.U. Cooke, J.C. Doornkamp. Geomorphology in Environmental Management. Oxford. Clarendon Press (1974)

6. J. Pethick. An Introduction to Coastal Geomorphology. (London. Edward Arnold. 1984)

7. A. Montes, S.S. Rodriguez, C.E. Dominguez. Aoelian research. 28. 58-70. (2017)

8. H. Th. Verstappen. Garis Besar Geomorfologi Indonesia. (Yogyakarta. Gadjah Mada University Press.) (2013) 
9. Y. Song, L. Liu, X. Li, J. Wang, W. Tuo, Y. Liu. J Geographical Science. 16. 495-501. (2006)

10. I.M. Susmayadi, Sunarto, M.A. Marfai. Penaksiran Multirisiko Bencana di Wilayah Kepesisiran Parangtritis. (Yogyakarta. Pusat Studi Bencana Universitas Gadjah Mada) (2009)

11. Z. Dong, X. Liu, H. Wang, Z. Wang. Sedimentary Geology. 161. 71-83. (2003)

12. Z. Dong. Z. Zhang, P. Lu, G. Qian. Journal of Arid Environments. 75. 865-869. (2011)

13. R.L. Martin. J.F. Kok. C.H. Hugenholtz. T.E. Barchyn. M. Vhamecki. J.T. Ellis. Aeolian Research. 30. (2018)

14. R.A. Bagnold. Proc. of the Royal Society of London. 167. (1938)

15. S.J. Blott. A Grain Size Distribution and Statistics Package for the Analysis of Unconsolidated Sediments by Sieving or Laser Granulometer. Gradistat v4. (Department of Geology Royal Holloway University of London) (2000)

16. C. Garcia-Lozano, J. Pinto, P. Daunis-i-Estedella. Estuarine, Coastal and Shelf Science. 208. (2018) 